\title{
PEMIKIRAN KEBANGSAAN K.H. ACHMAD SIDDIQ DAN IMPLIKASINYA DALAM MEMANTAPKAN IDIOLOGI PANCASILA SEBAGAI DASAR NEGARA DI INDONESIA
}

\author{
Syamsun Ni'am \\ Institut Agama Islam Negeri Tulungagung \\ Jl. Mayor Sudjadi Timur, No. 46 Tulungagung, Jawa Timur 66221 \\ E-mail:niamstainjbr@gmail.com \\ Anin Nurhayati \\ Institut Agama Islam Negeri Tulungagung \\ Jl. Mayor Sudjadi Timur, No. 46 Tulungagung, Jawa Timur 66221 \\ E-mail:niamstainjbr@gmail.com
}

\begin{tabular}{c|c|c}
\hline Received: & Revised: & Approved: \\
27/05/2018 & $27 / 05 / 2018$ & $20 / 09 / 2018$ \\
\hline
\end{tabular}

DOI: http://dx.doi.org/10.32332/akademika.v23i2.1106

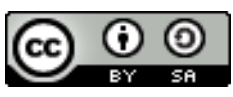

Pemikiran Kebangsaan K.H. Achmad Siddiq dan Implikasinya dalam Memantapkan Idiologi Pancasila Sebagai Dasar Negara di Indonesia Licensed Under a Creative Commons Attribution-ShareAlike 4.0 International License

\begin{abstract}
This article addresses an interesting phenomenon of this recent decade in the national journey of Indonesia, where there are some people or certain groups who want to distort or even question Pancasila as the common platform and Indonesian ideology. It is very urgent to examine the thoughts of the charismatic figure of Indonesia, K.H. Achmad Siddiq who has an idea about the relationship among religion, the State, more specifically about the position of Pancasila, and Islam or vice versa, particularly when Indonesia is
\end{abstract}


faced with the movements of the Pancasila de-ideologization which recently comes up to the surface. The most interesting idea of K.H. Acmad Siddiq is "Pancasila as the national ideology of Indonesian is final, no need to be questioned again, and is not against Islam, even it can go along and fill each other». Kyai Siddiq $>$ s view then brings fundamental implications in stabilizing Pancasila as a foundation of the social life, nation and state. This thought is then regarded as the genuine thought of a pesantren scholar.

Keywords: Nationality, Islam, Pancasila, and K.H. Achmad Siddiq.

\begin{abstract}
Abstrak
Artikel ini ditulis karena adanya fenomena menarik pada dekade mutakhir ini dalam perjalan kebangsaan di Indonesia, di mana ada sebagian orang atau kelompok tertentu yang ingin mendistorsi bahkan mempersoalkan Pancasila sebagai common platform dan idiologi bangsa Indonesia. Sangat urgent mengkaji pemikiran sosok ulama kharismatik Indonesia, K.H. Achmad Siddiq yang memiliki gagasan menyangkut hubungan agama dan Negara - lebih khusus tentang kedudukan Pancasila dan Islam atau sebaliknya, di saat Indonesia dihadapkan pada gerakan/upaya de-ideologisasi Pancasila yang akhir-akhir ini muncul ke permukaan. Gagasan paling menarik dari K.H. Acmad Siddiq adalah "Pancasila sebagai idiologi bangsa Indonesia sudah final, tidak perlu diotakatik lagi, dan tidak bertentangan dengan Islam, bahkan dapat berjalan bersama dan saling mengisi". Pandangan Kyai Siddiq ini kemudian membawa implikasi mendasar dalam memantapkan Pancasila sebagai landasan dalam perikehidupan bermasyarakat, berbangsa dan bernegara di Indonesia. Pemikiran inilah yang kemudian dianggap sebagai pemikiran genuin dari seorang ulama pesantren K.H. Acmad Siddiq.
\end{abstract}

Kata Kunci: Kebangsaan, Islam, Pancasila, dan K.H. Achmad Siddiq

\title{
A. Pendahuluan
}

Artikel ini ditulis didasarkan kepada suatu pertimbangan ataskegelisahan penulis terhadap munculnya beberapa gerakan dari sebagian kelompok kecil di negeri ini yang ingin menggugat tentang eksistensi Pancasila sebagai ideologi dan common platform bangsa Indonesia. Di samping itu, juga munculnya fenomena berbagai krisis kemanusiaan dan pemahaman keberagamaanyang melanda berbagai belahan dunia,tidak hanyaterjadi di Timur Tengah yang dianggap sebagai pusat peri-peri Islam, 
namun juga di dunia Barat/Eropa. Krisis tersebut sedikit atau banyak akan berdampak pada situasi dan kondisi di Indonesia, baik menyangkut persoalan sosial, budaya, ekonomi, agama, maupun politik. Hal tersebut terjadi paling tidak dikarenakan empat persoalan mendasar.Pertama, adanya perkembangan yang begitu cepat sebagai akibat dari arus informasi seiring dengan cepatnya arus globalisasi dan modernisasi di segala bidang yang melanda seluruh dunia. Sebagai akibatnya, munculnya gaya dan pola hidup yang serba praktis-pragmatis, materialistis, konsumeristis, dan individualistis, yang membawa kepada hilangnya jati diri manusia sebagai makhluk yang mestinya harus berhubungan secara normal dan natural baik secara individu maupun sosial. Kedua, jargon demokrasi yang selama ini menjadi ruh dan semangat berkebangsaan juga mulai memudar seiring dengan perkembangan interpretasi yang disalahartikan, sehingga berakibat munculnyadisharmoni dan disstabilisasi dalam berbagai aspek kehidupan. Demokrasi yang awalnya memiliki misi suci, yaitu ingin menegakkan supremasi di berbagai aspek kehidupan. Akan tetapi misi demokrasi itu justru memunculkan ketidakadilan, keserakahan, dan kesewenangwenangan dari yang kuat baik secara modal maupun politik, terhadap yang lemah secara ekonomi dan politik.Ketiga, munculnya radikalisasi atas nama agama di berbagai belahan dunia - termasuk di Indonesia - , juga dianggap sebagai pemicu terhadap lunturnya nilai-nilai dan prinsip demokrasi itu sendiri. Padahal dalam kajian-kajianyang telah lalu, demokrasi tidaklah bertentangan dengan agama (Islam), bahkan bisa berjalan seirama dengan Islam.Hal ini terjadi sebagai akibat dari disorientasi pemahaman agama yang tidak komprehensip, sehingga berakibat kepada munculnya gerakan (aksi) yang kontras dengan nurani manusia pada umumnya.

Keempat, dalam konteks Indonesia, munculnya sebagian kecil kelompok yang mempersoalkan kembali tentang dasar Negara, Pancasila sebagai common platform dan ideologi bangsasebagai akibat dari pemahamannyayang tidak integratif dan komprehensip dalam konteks keIndonesiaan, sehingga konsekuensinya adalah adanya pemaksaan untuk merumuskan kembali bahkan sudah mengarah kepadapenggantian ideologi Pancasila dengan ideologi lainnya. Misalnya yang baru-baru ini muncul, yaitu pemaknaan dan pemaksaan - dari HTI (Hitbuz Tahrir Indonesia) dan sebagian lainnya - tentang ideologi Pancasila yang dianggap sebagai produk demokrasi dan tidak sejalan dengan Islam.Oleh karena itu, 
demokrasi dan Pancasila dianggap sebagai produk thaghut (kafir). Inilah yang kemudian menjadi pemicu terhadap kegelisahan sebagian besar (mayoritas) masyarakat Indonesia, dimana sejak awal berdirinya Republik Indonesia ini, dan Pancasila telah dipilih sebagai ideologi dan common platform adalah keputusan final bersama founding fathers dan seluruh rakyat Indonesia, namun saat ini justru ada pihak-pihak yang ingin mengotakatik kembali. Hal ini dianggap tidak realistis dan mengada-ada. Dalam kontekks ini, maka segala upaya untuk membendung pemaknaan dan pemaksaan yang melanggar konstitusi ini harus dilakukan oleh seluruh elemen bangsa - termasuk oleh pemerintah. Oleh karena itu, upaya yang dilakukan pemerintah dengan menerbitkan Peraturan Pengganti Undangundang (Perpu) No. 2 tahun 2017 tentang ormas yang bertentangan dengan Pancasila beberapa waktu lalu, kiranya patut diapresiasi sebagai langkah konkrit dan antisipatif terhadap rongrongan ideologi bangsa (Pancasila). Sebab sudah bukan rahasia lagi bahwa kebijakan tersebut sebelumnya tidak atau belum secara tegas melarang suatu organisasi apapun bentuknya yang telah nyata-nyata melanggar dan merongrong Pancasila sebagai ideologi bangsa.Saat ini menjadi momen yang paling tepat untuk merespon dan mengcounter terhadap segala upaya pengkhianat ideologi bangsa sebelum rongrongan itu menjadi meluas dan menggerogoti sendi-sendi kehidupan bermasyarakat, berbangsa dan bernegara di Indonesia.

Tulisan ini menemukan momentumnya di saat bangsa Indonesia sedang dihadapkan pada disintegrasi pemahaman tentang pentingnya menjaga persatuan dan kesatuan dalam wadah NKRI dan ideologi Pancasila. K.H. Achmad Siddiq adalah sosok ulama kharismatik Nusantara yang memiliki kontribusi besar dalam peneguhan kembali akan pentingnya menjaga ideologi Pancasila dari rongrongan pihak luar - baik secara nyata dan laten - untuk merubah atau menggantinya. Sebab Pancasila dipilih sebagai ideologi bukanlah asal-asalan, namun melalui perjuangan (jihad) panjang dan hasil kesepakatan (ijtihad) bersama bangsa Indonesia. Segala upaya perongrongan terhadap ideologi yang telah disepakati bersama, sama halnya tidak mengakui hasil jihad dan ijtihad para founding fathers(pendiri bangsa) tersebut.Hal ini sekaligus dapat dikatakan sebagai bentuk pengkhianatan terhadap prinsip dasar kebangsaan di Indonesia. K.H. Achmad Siddiq adalah ulama kontemporer NU yang berhasil meyakinkan pada khalayak di tahun 1980-an pada saat semua 
organisasi politik maupun ormas lainnya belum berani secara tegas/raguragu (enggan) untuk menyatakan menerima Pancasila sebagai azas dalam berorganisasi. Bagi K.H. Achmad Siddiq, Pancasila dianggap sebagai ideologi paling tepat dan sudah final, tidak bisa diutak-atik lagi, dan harus dipertahankan bersama sampai kapanpun di Indonesia. Pancasila adalah alat pemersatu bangsa di Indonesia.Dalam konteks saat ini, Pancasila justru dapat dijadikan contoh paling ideal sebagai ideologi bangsa di Indonesia, di saat dunia telah mengalami ujian berat terhadap pemaknaan dan implementasi ideologi yang dianut di Negaranya masing-masing, khususnya saat ini yang terjadi di Timur Tengah.Pemikiran genuine K.H. Achmad Siddiq dalam dinamika kebangsaan di Indonesia ternyata telah membawa pengaruh yang sangat besar terhadap faham kebangsaan yang dianut oleh -khususnya warga Nahdliyyin (NU) - masyarakat Indonesia hingga saat ini.

\section{B. Diskursus Pancasila dan Islam}

Dalam sejarahnya yang panjang, diskursus Pancasila muncul pertama kali sebenarnya menjelang Indonesia merdeka dengan dibentuknya BPUPKI (Badan Persiapan Usaha Panitia Kemerdekaan Indonesia) pada tanggal 29 April 1945 oleh pemerintah Jepang untuk mempersiapkan kemerdekaan Indonesia. Pada setiap sidang telah terjadi perdebatan ideologis yang sangat seru. Hal itu dipicu oleh pidato Soekarno yang merepresentasikan lima asas sebagai dasar negara, yaitu:Kebangsaan Indonesia, Internasionalisme atau Peri Kemanusiaan, Mufakat atau Demokrasi, Kesejahteraan Sosial dan Ketuhanan. Lima asas ini dinamakan Pancasila. ${ }^{1}$

Berbeda dengan lima dasar yang telah disampaikan Soekarno, pada tanggal 29 Mei 1945 di depan sidang BPUPKI, Muhamad Yamin menyampaikan lima asas dasar negara, yaitu: Peri Kebangsaan, Peri Kemanusiaan, Peri Ketuhanan, Peri Kerakyatan dan Kesejahteraan Rakyat. Yamin, sebagaimana dikutip Supomo, tepatnya pada tanggal 31 Mei 1945 di depan sidang BPUPKI menyatakan: "Memang di sini terlihat ada dua faham, yaitu faham dari anggota-anggota ahli agama yang menganjurkan supaya Indonesia didirikan sebagai negara Islam; dan anjuran lain sebagaimana telah dianjurkan oleh Muhamad Hatta, yaitu negara persatuan nasional 1961).

\footnotetext{
${ }^{1}$ Baca Soekarno, Lahirnya Pancasila, dalam Tujuh Bahan Indoktrinasi (Jakarta: DPA,
} 
yang memisahkan urusan negara dan urusan Islam. Dengan perkataan lain, bukan negara Islam".

Dalam konteks itulah, Prawoto Mangkusasmito pernah memberikan gambaran bahwa dalam naskah persiapan UUD 1945 jilid I yang disusun oleh Muhamad Yamin hanya dicantumkan tiga pidato terpenting yang mewakili para nasionalis sekuler saja, yaitu pidato Soekarno(1 Juni 1945), pidato Muhamad Yamin (29 Mei 1945), dan pidato Supomo (31 Mei 1945). Sementara itu, tidak ada satu pun pidato dari para anggota nasionalis Muslim yang dicantumkan. ${ }^{2}$ Hal ini menunjukkan bahwa ada ketegangan perihal perlakuan politis dari nasionalis sekuler terhadap nasionalis Muslim. Oleh karena itu, kelihaian dan kepiawaian diplomasi politik dari nasionalis Muslim untuk memasukkan kepentingan-kepentingan Islam demi masa depan bangsa Indonesia - yang mayoritas masyarakatnya adalah Muslim -, menjadi sebuah kewajiban.

Berdasar atas dinamika perpolitikan nasional yang memanas tersebut, makamuncullah upaya dalam menengai ketegangan yang terjadi, dibentuklahtim sembilan yang terdiri dari Soekarno, M. Hatta, A. Subarjo, M. Yamin, A. A. Maramis dari golongan nasionalis sekuler; sementaradari pihak golongan nasionalis Muslim terdiri dari Agus Salim, A. Wahid Hasyim, Abikusno, dan Abdul Kahar Muzakir. Melalui perdebatan panjang, akhirnya upaya kompromi dapat dicapai pada tanggal 22 Juni 1945, yang menyatakan bahwa dasar negara Indonesia adalah Pancasila (lima dasar), dengan menambahkan tujuh patah kata di dalam sila pertama, yaitu: Ketuhanan dengan kewajiban menjalankan syari'at Islam bagi para pemelukpemeluknya. Sedang sila-sila selanjutnya sama dengan pancasila yang kita kenal hingga sekarang ini.

Tidak hanya berhenti di situ, sidang BPUPKI terus dilanjutkan dengan membentuk PPKI (Panitia Persiapan Kemerdekaan Indonesia) yang terdiri atas 15 orang. Golongan nasionalis Muslim dalam kepanitiaan PPKI hanya diwakili oleh dua orang, yaitu Ki Bagus Hadikusumo dan KH. A. Wahid Hasyim, sehingga representasi kepentingan Islam telah dipatahkan dan selalu kalah dalam persidangan. Bahkan, sehari setelah Proklamasi, tujuh kata dalam Piagam Jakarta tersebut berhasil dihilangkan. Hal ini menunjukkan betapa kekalahan polilik Islam dalam pembentukan

2 Prawoto Mangkusasmito, Pertumbuhan Historis Rumus Dasar Negara dan Sebuah Proyeksi (Jakarta: Hudaya, 1970). 
dasar negara Pancasila. ${ }^{3}$ Kenyataan pahit ini memang harus diterima. Bagaimanapun juga terbukti bahwa golongan nasionalis sekuler lebih piawai dalam politik dibanding golongan nasionalis Muslim.

Deliar Noer beranggapan bahwa golongan nasionalis Muslim bereaksi pasif, tidak memberikan tanggapan atau protes terhadap penghapusan tersebut, dikarenakan beberapa pertimbangan, antara lain: Pertama, nasionalis Muslim yang menerima penghapusan tujuh kata dalam sila pertama tersebut adalah atas lobi Muhamad Hatta dalam pembicaraan mereka, yang terjadi pada pagi harinya, 18 Agustus 1945 untuk kepentingan persatuan bangsa,sehinggakata "Ketuhanan" ditambah menjadi "Ketuhanan Yang Maha Esa". Golongan Muslim menganggap "Ketuhanan Yang Maha Esa" adalah nama lain dari tauhid yang dikenal dalam Islam. Sebab hanya dalam Islam yang hanya mengenal Ke-Esaan Tuhan (tauhid).

Kedua, suhu politik sehari setelah proklamasi kemerdekaan - terutama di Jakarta - mengalami ketegangan sangat tinggi. Dalam situasi seperti ini, negara perlu diredam agar situasi dingin menyelimuti Jakarta dan bumi Indonesia, dan Indonesia berada dalam kondisi yang baru saja merdeka untuk menedapatkan konstitusi secara cepat dan cocok bagi semuanya. Ketiga, tidak berselang terlalu lama, enam bulan setelah proklamasi kemerdekaan Indonesia, golongan Muslimmengusulkan ada pemilihan umum yang diikuti oleh semua pihak (golongan nasionalis). Golongan Muslim sangat optimis bahwa proklamasi kemerdekaan ini akan diikuti oleh stabilitasasi melalui pemilu yang akan dilangsungkan. Golongan Muslim sangat optimis akan dapat memenangkan pemilu, sebabmayoritas jumlah penduduk Indonesia adalah penganut Islam. ${ }^{4}$

Prediksi kalangan Muslim ternyata meleset dengan kekalahan secara politik pada pemilihan umum yang telah dilaksanakan. Pada era pasca kemerdekaan pertentangan dua kubu -golongan Muslim dan sekuler - nampaknya terus berlanjut pada saat sidang Majlis Konstituante, kalangan Muslim mengusulkan kembali "Islam sebagai dasar negara”. Akan tetapi, setelah dilakukan pengambilan suara terbanyak 52\% mendukung Pancasila sebagai ideologi negara, dan hanya $48 \%$ yang mendukung Islam

\footnotetext{
${ }^{3}$ Andar Nubowo, "Islam dan Pancasila di Era Reformasi: Sebuah Reorientasi Aksi," n.d., 18 .

${ }^{4}$ Deliar Noer, Gerakan Modern Islam di Indonesia 1900-1942 (Jakarta: LP3ES, 1996).
} 
sebagai ideologi negara. Hal ini menunjukkan kekalahan golongan Muslim dalam perpolitikan nasional pada saat itu.

M. Natsir adalah di antara tokoh golongan nasionalis Islam yang gencar mengusulkan ideologi Islam sebagai dasar negara. Bagi Natsir, Pancasila diambil dari pemikiran dan konsep manusia sekuler, walaupun di dalamnya ada rumusan "Ketuhanan". Sila ini tidaklah berasal dari wahyu Tuhan, Pancasila adalah hasil penggalian dari masyrakat Nusantara. Di samping itu, Natsir memiliki argumen bahwa mayoritas masyarakat Indonesia adalah beragama Islam, sehingga hal ini juga didasarkan kepada ajaran Islam mayoritas, sehingga sangat tepat jika Islam dijadikan dasar negara, bukan Pancasila. Alasan lain dari Natsir adalah agama Islam telah sempurna untuk mengatur hajat hidup bernegara dan bermasyarakat dan dapat menjamin hidup semua golongan. Pendapat Natsir di atas terus mendapatkan apresiasi dan dukungan khususnya dari tokoh-tokoh Muslim, antara lain: Kasman Singodimejo (Masyumi), K.H. Masykur, dan K.H. Saefuddin Zuhri (NU). Walaupun kalangan Muslim menelan pahit kekalahan secara politik, namun itulah realitas politik yang harus diterima oleh semua pihak, sehingga Pancasila harus dijadikan idiologi dan common platformbersama dalam hidup bermasyarakat, berbangsa dan bernegara di bumi Indonesia hingga kini.Oleh karena itu, melalui proses sejarah yang sangat panjang dengan menggali segala potensi yang dimiliki oleh masyarakatnya, perdebatan sengit yang pernah terjadi tersebut, hendaknya diapresiasi, dihargai, dan dijaga untuk tetap dilaksanakan secara konsisten dan konsekuen.

Dalam pandangan Nurcholis Madjid, Pancasila dianggap sebagai sesuatu yang benar - sebagai konsensus bersama seluruh komponen bangsa - , baik dilihat dari isi maupun kedudukannya sebagai kalimah sawa' bagi kehidupan berbangsa bersama pemeluk agama lain. Kesepakatan tentang dipercayainya Tuhan Maha Esa pada sila pertama, sebenarnya telah cukup baik. Apalagi ditambah dengan kesepakatan-ksepakatan yang lain, yaitu keempat sila berikutnya. Di atas kalimah sawa' inilah umat Islam bersama pemeluk agama lain dapat bekerjasama untuk kepentingan masyarakat. ${ }^{5}$ Dalam konteks ini, Mujamil Qomar memberikan penegasan,

${ }^{5}$ Nurcholish Madjid, Islam Indonesia Menatap Masa Depan: Aktualisasi Ajaran Ahlussunnah Waljama'ah", dalam Akhmad Sahal dan Munawir Aziz (ed.), Islam Nusantara: Dari Ushul Fiqh hingga Paham Kebangsaan, Cet. II (Bandung: Mizan, 2015). 
bahwa mereka bisa hidup bertetangga, berkelompok bersama, bekerja bakti bersama, bergaul dalam kehidupan sehari-hari, menempuh pendidikan dalam lembaga yang sama, saling tegur sapa, saling membantu, berolah raga dalam klub yang sama, dan saling menjaga nama baik bangsa dan Negara yang mereka cintai ini. Pada masa penjajahan dahulu, mereka juga berjuang bersama untuk mengusir penjajah dari tanah air ini. ${ }^{6}$

Demikian esensi sebenarnya dari apa yang terkandung di dalam Pancasila. Kata kunci dari implementasi nilai-nilai Pancasila adalah toleransi (tasamuh). Toleransi atas keberagaman yang ada di bumi pertiwi ini menjadi sangat penting ketika dihadapkan kepada pluralitas (kebhninnekaan) yang ada. Oleh karena itu toleransi yang dibangun di atas keyakinan adanya saling menghormati dan menghargai perbedaan, akan dapat menciptakan harmonisasi kehidupan. Harmonisasi kehidupan yang telah terbangun akan dapat menumbuhkan kedamaian di antara warga bangsa. Oleh karena itu, keberagaman (pluralitas/kebhinnekaan) hendaknya dibiarkan secara natural untuk berkembang dan berdialektika dengan kehidupan yang ada, sehingga keotentikan dari nilai-nilai keberagaman tersebut menjadi kekayaan yang dapat mendorong warga bangsa untuk bisa hidup saling berdampingan dan saling membantu dalam membangun bangsa.

\section{Pemikiran Kebangsaan K.H. Achmad Siddiqtentang Relasi Pancasiladan Islam}

K.H. Achmad Siddiq (selanjutnya disebut Kyai Siddiq)yang lahir di Jember pada 10 Rajab 1344 H/24 Januari 1926 M), dan meninggal dunia pada 7 Rajab 1411 H/23 Januari 1991,7 dikenal sebagai ulama kharismatik NU (Nahdlatul Ulama) yang memiliki kedekatan dengan berbagai pihak. Kepiawaian Kyai Siddiq dalam menjalin komunikasidan berdiplomasi baik dengan penguasa, pengusaha, masyarakat biasa,

${ }^{6}$ Mujamil Qomar, Fajar Baru Islam Indonesia?Kajian Komprehensif atas Arah Sejarah dan Dinamika Intelektual Islam Nusantara (Bandung: Mizan, 2012).

${ }^{7}$ Biografi lengkap tentang sosok dan kiprah K.H. Achmad Siddiq dalam percaturan pemikiran dan gerakan Islam di Indonesia dapat dilihat pada Afton Ilman Huda, Biografi Mbah Siddiq (Jember: Pon. Pes. Al-Fattah, n.d.), 179; Syamsun Ni'am, The Wisdom of K.H. Achmad Siddiq: Membumikan Tasawuf, (Jakarta: Erlangga Press, 2009); Munawar Fuad Noeh dan Mastuki HS, ed., Menghidupkan Ruh Pemikiran K.H. Achmad Siddiq, 1 ed. (Jakarta: Logos, 1999); "Kyai Achmad," in AULA: Risalah NU, vol. 8, 2 (Surabaya: PWNU Jawa Timur, 1991), 11. 
tokoh-tokoh nasionalis,ulama yang berseberangan pandangan dengannya, hingga dengan tokoh lintas agama, suku, budaya,etnis, dan lain sebagainya, adalah modal utama yang dimiliki Kyai Siddiq dalam menjembatani(memediasi) berbagai persoalan yang dihadapi ummat saat itu.Karena itulah Kyai Siddiq dikenal sebagai sosok ulama populis yang dimiliki NU dan Indonesia.Dalam konteks ini, tidaklah berlebihan jika Mujamil Qomar mengelompokkan Kyai Siddiq sebagai ulama yang memiliki tipologi responsif, yaitu ulama yang memiliki pemikiran yang condong memberikan jawaban atas berbagai persoalan yang sedang dihadapi ummat. Ciri dari tipologi responsif adalah cepat tanggap, suka merespons, memiliki kepekaan yang tinggi terhadap fenomena sosial, dan berusaha menawarkan solusi.

Persoalan yang mengemuka saat itu (tahun 1980-an) adalah munculnya disinterpretasi tentang Pancasila sebagai azas berfikir dan bertindak dalam hidup bermasyarakat, berbangsa dan bernegara. Kyai Siddiq adalah tokoh ulama yang paling getol dalam memperjuangkan penerimaan Pancasila sebagai ideologi dan common platform di Indonesia di saat ummat Islam merasa curiga terhadap rencana pemerintah Orde Baru menerapkan azas tunggal Pancasila bagi organisasi sosial dan politik $^{8}$. Melalui berbagai rapat, seminar, simposium, hingga lokakarya, Kyai Siddiq sangat piawai menawarkan gagasannya dengan argumentasi pedagogis dan religius, sampai akhirnya NU berhasil diyakinkan untuk pertamakalinya menerima Pancasila secara tegas sebagai azas dalam berorganisasi, yang kemudian diikuti oleh organisasi keagamaan lainnya - yang awalnya secara tidak tegas atau ragu bahkan curiga dalam menentukan sikap atas penerimaan Pancasila sebagai azas tunggal. Kyai Siddiq memiliki argumen bahwa "penerimaan Pancasila sebagai dasar negara Indonesia didasarkan atas prinsip pertama, kaum Muslimin Indonesia, melalui para pemimpinnya ikut aktif dalam merumuskan dan kesepakatan menetapkan UndangUndang Dasar Negara ini; dan kedua, nilai-nilai luhur Pancasila yang dirumuskan dalam pembukaan UUD 1945 menjadi Dasar Negara dapat disepakati dan dibenarkan menurut pandangan Islam. Oleh karena itu, kaum Muslimin Indonesia, secara bersama-sama dengan seluruh bangsa

${ }^{8}$ Mujamil Qomar, NU "Liberal" dari Tradisionalisme Ahlussunnah ke Universalisme Islam (Bandung: Mizan, 2002). 
Indonesia memikul tanggung jawab untuk memenuhi dan melaksanakan kesepakatan bersama itu". ${ }^{9}$

Menurut Kyai Siddiq, dalam hubungan agama dan Pancasila, keduanya dapat sejalan, saling menunjang dan saling mengokohkan. Keduanya tidak bertentangan dan tidak boleh dipertentangkan, keduanya harus bersama-sama dilaksanakan dan diamalkan, tidak harus dipilih salah satu dengan sekaligus membuang dan menanggalkan yang lainnya. Bagi Kyai Siddiq, sungguh tepat kebijaksanaan pemerintah bahwa Pancasila tidak akan diagamakan dan agama tidak akan dipancasilakan. Walaupun dalam praksisnya memang tidak mudah untuk menerapkannya. ${ }^{10}$

Dalam konteks yang sama, Kyai Siddiq juga memberikan ilustrasisebagaimana dikutip Mujamil Qomar - sebagai berikut: “Sesungguhnya salah satu masalah besar bagi bangsa Indonesia zaman ini adalah bagaimana memproporsionalisasikan (wadl'u syai' fi mahallih) Pancasila dan agama, sehingga benar-benar terbukti bahwa di dalam negara dan masyarakat berpancasila ini agama dapat diamalkan dengan lebih baik, dan sebaliknya, umat beragama di negara ini merupakan tulang punggung ideologi nasional Pancasila. ${ }^{11}$

Ijtihad Kyai Siddiq perihal hubungan harmonis Pancasila dan Islam, yang kemudian menjadi keputusan resmi dari sikap NU pada Munas (Musyawarah Nasional) alim ulama di Situbondo tahun 1983 tentang penerimaan Pancasila merupakan kristalisasi dari nilai-nilai akidah, syari'ah, dan akhlaq Islam Ahlussunnah wal Jama'ah, maka pengamalan Pancasila dengan sendirinya telah merupakan pelaksanaan syari'at Islam ala Ahlussunnah wal Jama'ah. Sebagai konsekuensi dari sikap tersebut, NU berkewajiban mengamankan pengertian yang benar tentang Pancasila, dan pengamalannya secara murni dan konsekuen oleh semua pihak. Dengan demikian tidak perlu ada aspirasi lagi untuk mendirikan

${ }^{9}$ Humaidy Abdussami Ridwan Fakla AS.(Ed.), Biografi 5 Rais 'Am Nahdlatul Ulama (Yogyakarta: LTn-NU dan Pustaka Pelajar, 1995).

${ }^{10}$ K.H. Achmad SIddiq, "Hubungan Agama dan Pancasila," in Pertemuan Ilmiah (Peranan Agama dalam Memantapkan Ideologi Negara, Jakarta: Balitbang Agama Departemen Agama RI, 1985), 14. Islam.

${ }^{11}$ Mujamil Qomar, NU "Liberal" dari Tradisionalisme Ahlussunnah ke Universalisme 
Negara Islam, karena nilai-nilai dan aspirasi Islam telah terdiskripsikan di dalam Pancasila. ${ }^{12}$

Hal tersebut membawa implikasi signifikan dan diikuti oleh seluruh komponen bangsa. Penerimaan para kyai/ulama NU tersebut paling tidak di dasarkan kepada dua hal. Pertama, tidak ditemukan satu sila pun dalam Pancasila yang bertentangan dengan al-Qur'an dan alHadis. Bahkan sila-silanya selaras dengan pokok-pokok ajaran Islam. Kedua, dari sudut realitas politik, Pancasila ini dapat menjadi payung politik yang menyatukan seluruh warga bangsa yang sangat plural, baik etnis, suku, dan agama. Para kyai/ulama menyadari bahwa jika al-Qur'an dan al-Hadis dipaksakan sebagai asas dan konstitusi Negara Indonesia, maka Indonesia akan terancam disintegrasi yang mengarah pada konflik yang tiada henti. Dengan mendasarkan kepada kaidah ushul fiqh, "dar' al-mafasid muqaddamun ala jalb al-manafi', (menolak kerusakan lebih didahulukan daripada mengambil kemanfaatan)", maka para kyai/ulama NU tidak ragu menerima Pancasila sebagai asas dalam bernegara dan bukan asas dalam beragama (Islam). ${ }^{13}$

Lebih lanjut Kyai Siddiq memberikan argumentasi logis bahwa Pancasila adalah ideologi dan Islam adalah Agama.Ideologi pada umumnya diartikan dengan cita-cita, filsafat, program perjuangan, strategi, sasarannya, dan sebagainya.Tak dapat dipungkiri, karena kompleksnya hal-hal yang terkandung dalam ideologi, sehingga mampu mempengaruhi watak dan tingkah laku penganutnya dalam kehidupan sehari-hari, sehingga ada yang secara berlebih-lebihan menganggap bahwa "ideologi adalah agama".Padahal bagaimanapun hebatnya ideologi yang dibangun,ia tetap hasil pemikiran manusia, dan tidak akan sampai ke derajat agama.Sedangkan Islam adalah wahyu Allah, bukan hasil pemikiran manusia, bahkan bukan hasil pemikiran Rasulullah saw. Islam adalah wadl'un Ilahiyun, ciptaan Allah swt.Oleh karena itu, agama tidak boleh disetingkatkan dengan ideologi. Dengan kata lain, agama bukanlah ideologi. Namun Islam dapat -bahkan seharusnya - membimbing manusia

${ }_{12}$ Said Aqil Siroj, Islam Sumber Inspirasi Budaya Nusantara Menuju Masyarakat Mutamaddin (Jakarta: LTN NU, 2014).

13 Baca Abdul Moqsith Ghazali, "Metodologi Islam Nusantara" Akhmad Sahal Munawir Aziz, Baca Abdul Moqsith Ghazali, "Metodologi Islam Nusantara", dalam Islam Nusantara: Dari Ushul Fiqh hingga Paham Kebangsaan, Cet. II (Bandung: Mizan, 2015), 10910. 
merumuskan suatu ideologi yang benar. Islam dapat -dan seharusnyamenilai apakah suatu ideologi itu benar atau salah.Islam menolak ideologi yang tidak sesuai atau bertentangan dengan Islam, dan hanya dapat menerima ideologi yang sesuai, sejalan dan tidak bertentangan dengan Islam. ${ }^{14}$

Umat Islam menerima Pancasila, menurut Kyai Achmad, bukan sekedar taktik melainkan ada tiga pertimbangan.Pertama, umat Islam Indonesia -melalui para pemimpinnya-ikut aktif dalam perumusan dan kesepakatan tentang dasar negara itu. Sembilan tokoh utama bangsa yang terkenal dengan Panitia Sembilan, berhasil menyusun rancangan rumusan yang ketika itu disetujui oleh semua pihak dan akan dijadikan sebagai pembukaan Undang-Undang Dasar Negara (Piagam Jakarta), yang kemudian diterima dan disahkan dalam sidang pleno BPUPKI pada tanggal 14 Juli 1945. Kedua, secara substansial, nilai-nilai luhur yang dirumuskan menjadi dasar negara itu dapat disepakati dan dapat dibenarkan menurut pandangan Islam.Misalnya, sila "Ketuhanan Yang Maha Esa" mencerminkan pengertian tauhid (monoteisme murni) menurut akidah Islam (lihat QS. al-Ikhlash).Demikian pula mengenai empat sila berikutnya.Kalau ditampilkan satu persatu maka tidak ada satupun yang bertentangan dengan agama -khususnya Islam.Bahkan urutan-urutan Pancasila itu dapat dibaca dalam kerangka "amanu wa 'amilu al-shalihat". Kalau soal pertama dianggap sebagai pencerminan amanu, maka kiranya tidak keliru kalau empat sila berikutnya dapat dianggap mencerminkan 'amilu al-shalihat.Ketiga, umat Islam berkepentingan dengan memantapkan peranan agama dalam penghayatan dan pengamalan ideologi nasional dan sebaliknya, negara Pancasila, agama terhayati dan teramalkan secara lebih baik.Bukan hanya karena mayoritas rakyat Indonesia beragama Islam, tetapi karena pada diri Islam sendiri memuat dan membawa nilai-nilai luhur yang bersumber pada wahyu yang dapat memberi kontribusi bagi pembangunan nasional dan dalam pembinaan hukum nasional.

Dengan demikian, menurut Kyai Siddiq, Pancasila merupakan satu rangkaian kesatuan, tidak boleh mengambil satu sila dan meninggalkan sila yang lain. Hal demikian juga mengandung pengertian, bahwa pemahaman utuh terhadap Pancasila merupakan sebuah keniscayaan. Kyai Siddiq mengibaratkan: "Sebuah ramuan, bisa saja terjadi perbedaan peran dari tiap-tiap

\footnotetext{
${ }^{14}$ K.H. Achmad SIddiq, "Hubungan Agama dan Pancasila."
} 
bumbu, tetapi kelima bumbu harus ada, tidak boleh ada yang ditinggal apalagi dibuang" ${ }^{15}$ Butir-butir elaboratif Pancasila dari Kyai Siddiq dapat dijelaskan sebagai berikut:

Sila pertama: Ketuhanan Yang Maha Esa. Kyai Siddiq memberikan perspektif dalam Islam, bahwa sila pertama adalah pemadu (semen) dan pemangku (pondamen) bagi sila-sila yang lain. Oleh karena itu, sila pertama ini menjadi landasan bagi sila-sila berikutnya. Kyai Siddiq lagilagi memberikan perumpamaan, ibarat makanan, sila pertama bagaikan ragi yang mempengaruhi (bahkan menentukan) warna, rasa, dan bahkan wujud makanan itu. Karena di dalam sila Ketuhanan Yang Maha Esa itu mengandung kepercayaan yang benar, yang teguh tak tergoyahkan tentang Tuhan Yang Maha Esa (al-iman); kesetiaan yang sungguh-sungguh dan ikhlas, menyesuaikan sikap dan tingkah laku perbuatan dengan kehendak ajaran Tuhan Yang Maha Esa (al-taqwa); dan kesadaran yang penuh dan mendalam, bahwa segala sikap dan tingkah laku perbuatan, selalu berada di bawah kekuasaan dan pengawasan Tuhan Yang Maha Esa (al-ihsan). Kyai Siddiqq melanjutkan elaborasinya bahwa yang dimaksud dengan Tuhan Yang Maha Esa itu adalah: "Dia, hanyalah Allah, Maha Tunggal (tiada sekutu, tiada pendamping, tiada pembanding, tiada penanding. Dia, Maha Sempurna (Maha Kuasa, Maha Mencipta Maha Bijaksana, Maha Tahu, Maha Pengatur, Maha Menentukan, dan Maha Abadi)". Demikian apiknya Kyai Siddiq dalam mengelobarasi sila pertama ini, yang dianggapnya sebagai landasan berfikir dan bersikap selanjutnya.Sila pertama bagi Kyai Siddiq, merupakan landasan bagi sila-sila berikutnya.Karena di dalamnya mengandung nilai-nilai religiusitas yang tinggi tidak hanya bagi ummat Islam tapi bagi semua agama yang hidup di bumi Indonesia.

Sila kedua: Kemanusiaan yang adil dan beradab. Menurut Kyai Siddiq, sila kedua ini mengandung pengertian kemanusiaan yang hakiki yang berkeadilan dan berkeadaban yang berakar pada prinsip persamaan martabat, sama-sama makhluk Allah swt. Oleh karena itu, bagi Kyai Siddiq, sila kedua ini merupakan pasangan yang logis dan serasi dengan sila pertama.Jika manusia sudah menempatkan kedudukannya pada tempat yang tepat, yaitu sebagai makhluk Allah, maka berarti telah menyadari

15 "Lihat Achmad Siddiq, 'Norma-norma Pancasila Menurut Pandangan Islam', Makalah yang rencananya akan disampaikan dalam seminar di Aceh, karena sesuatu hal, sehingga tidak jadi dipresentasikan, terjadi pada tahun 1970-an," n.d., 4. 
adanya prinsip persamaan martabat dan derajad.Tidak boleh ada perlakuan yang berada di luar batas-batas kemanusiaan. Konsekuensinya, tidak boleh lagi ada penindasan, pemerasan, penipuan, penjajahan oleh sebagian manusia atas manusia lainnya. Tidak boleh ada kultus dalam arti menempatkan manusia melebihi martabat kemanusiaan, mendewadewakan dan sebagainya.

Hal demikian sangat inheren dengan prinsip-prinsip ajaran Islam, yang sangat menghormati manusia dan aspek kemanusiaannya sebagai mahkluk Allah yang paling sempurna di antara makhluk-makhluk lainnya (ahsanu taqwim).Lebih lanjut Kyai Siddiq mengatakan, bahwa sila kedua ini sangat sejalan dengan Islam, sebab Islam mengajarkan tentang kemanusiaan bukan hanya memberikan tempat dan kesempatan yang sama di antara sesama manusia, tetapi juga mengadung kewajiban agar setiap manusia sesuai dengan kemampuannya berusaha untuk mendapatan tempat martabat, dan nikmat yang sama dan seimbang. Usaha demikian harus berlandaskan pada rasa kasih sayang yang tulus, ukhuwwah (persaudaraan), dan simpati terhadap sesamanya. Penjabaran dari sila kedua ini-menurut Kyai Siddiq-adalah mengandung penghormatan antara hak dan kewajiban secara seimbang di antara manusia itu, sehingga harkat dan martabat manusia tetap terjaga dan berjalan seimbang, tanpa dirusak atau merusak satu sama lainnya. Dengan demikian, sila kedua ini sangat kompetibel dengan ajaran dan nilai-nilai religius Islam itu sendiri, dan tidak bertentangan dengan ajaran dan prinsip agama lainnya.

Sila ketiga: Persatuan Indonesia. Allah swt.memang sengaja menciptakan manusia dengan berbagai macam suku, bangsa dan kelompok, dengan maksud agar saling mengenal; selanjutnya dapat saling membina, saling pengertian, saling hormat dan menghormati satu sama lainnya. Bangsa Indonesia adalah satu kelompok bangsa dengan sejumlah suku, etnis, budaya, bahasa, dan lainnya, yang telah terjalin selama berabad-abad dalam satu perasaan yang sama setanah air dan sebangsa. ${ }^{16}$ Keutuhan bangsa dan keutuhan wilayah Indonesia merupakan sebuah rahmat Allah yang tak tertandingi, sekaligus merupakan sarana dalam menggapai cita-cita kejayaan bangsa ke depan. Oleh karena itu, menurut

16 "Berdasarkan kajian mutakhir, bahwa Indonesia adalah Negara yang sangat plural, yang terdiri dari 17 ribu pulau lebih, 34 propinsi dan 516 kabupaten/kota, 714 suku, dan 1.211 bahasa daerah.," Jawa Pos, 18 Agustus 2017. 
Kyai Siddiq, semua itu harus disyukuri dengan mengembangkan rasa cinta kepada bangsa dan tanah air, juga kesediaan berkorban untuk kepentingan bangsa dan tanah air. Cinta dalam pengertian yang sesungguhnya, bukan cinta ashabiyyah (cinta buta) yang tidak mempertimbangkan kebenaran dan kebatilan.Inilah esensi dari sila "Persatuan Indonesia".Menurut Kyai Siddiq, bangsa yang kuat dan bahagia adalah bangsa yang bersatu dan saling menghargai, sehingga dapat membantu dan bahkan memelihara perdamaian dunia. Hanya bangsa yang kuat yang dapat berbuat untuk kepentingan bangsa-bangsa lain di dunia. ${ }^{17}$

Sila Keempat: Kerakyatan yang dipimpin oleh hikmat kebijaksanaan dalam permusyawaratan atau perwakilan. Kyai Siddiq memberikan elaborasi cukup fundamental dengan mengatakan, bahwa kerakyatan berarti orientasi kepada keinginan dan kepentingan rakyat, lazim disebut dengan demokrasi atau kedaulatan rakyat.Pengakuan dan kesadaran bahwa pada hakikatnya yang memiliki kedaulatan (kekuasaan memerintah) adalah rakyat itu sendiri secara bersama-sama. Kedaulatan, keinginan, dan kepentingan rakyat tersebut disalurkan dengan hikmat kebijaksanaan, cara yang sebaik mungkin, yang paling mendekati tujuan, paling bermanfaat, paling kecil resikonya, paling memberikan kepuasan bagi rakyat sebanyak-banyaknya. Kyai Siddiq melanjutkan bahwa sila kerakyatan ini sesuai dengan pesan Islam, yaitu sebagai pengejawantahan dari prinsip persamaan martabat antara sesama manusia.Di sini tidak ada hak monopoli atas yang lainnya.

Kata "hikmat kebijaksanaan" menurut Kyai Siddiq, adalah kerakyatan atau demokrasi yang dicita-citakan bukan liberalisme dalam arti kebebasan sebebas-bebasnya untuk merebut kemenangan suara dengan menggunakan segala cara, kekuatan dan kemampuan. Hikmat kebijaksanaan, membatasi sila kerakyatan ini dengan toleransi, kasih sayang, dan terutama tidak boleh memperkosa kebenaran dan keadilan dengan menggunakan esensi hikmat kebijaksanaan, tidak membenarkan kesewenang-wenangan mayoritas terhadap minoritas, dan demikian juga sebaliknya. Suka bermusyawarah menurut Islam bukanlah hanya metoda atau sistem yang baik dalam bernegara dan bermasyarakat, namun juga

17 “Lihat Achmad Siddiq, 'Norma-norma Pancasila Menurut Pandangan Islam', Makalah yang rencananya akan disampaikan dalam seminar di Aceh, karena sesuatu hal, sehingga tidak jadi dipresentasikan, terjadi pada tahun 1970-an," 10. 
mengandung pengertian tentang sikap mental, akhlak, dan budi pekerti yang luhur.Suka bermusyawarah berarti orang menyadari kelemahan diri sendiri dan menghargai orang lain, di samping berani mengeluarkan pendapat juga bersedia menerima pendapat orang lain; bersedia memberi peringatan, juga bersedia diberi peringatan dari pihak lain. Di sinilah muncul sikap saling korektif-konstruktif, tawashau bi al-haqq wa tawashau bi al-shabri (saling bernasehat tentang kebaikan dan kesabaran). ${ }^{18}$

Sila kelima: Keadilan sosial bagi seluruh rakyat Indonesia.Sila kelima ini merupakan muara dari sila-sila berikutnya.Inilah yang dicitacitakan seluruh bangsa Indonesia.Keadilan sosial menurut Kyai Siddiq, adalah keadilan yang mengejawantah pada segala bidang kehidupan masyarakat, berwujud kesejahteraan hidup rohaniah dan jasmaniah. Hal ini sesuai dengan prinsip dasar Islam, yaitu pencapaian fi al-dunya hasanah wa fi al-akhirati hasanah (kebahagiaan di dunia dan di akhirat sekaligus). Kedua kebahagiaan saling mempengaruhi satu sama lain. Oleh karena itu, cita-cita ideal tersebut merupakan dambaan bagi seluruh masyarakat Indonesia. Untuk mencapai keadilan sosial dalam wujud kesejahteraan yang merata bagi seluruh rakyat Indonesia, menurut Kyai Siddiq, hanya dapat dicapai melalui: Kerja keras oleh semua pihak, kesediaan berkorban oleh yang kuat untuk kepentingan yang lemah - bisa melalui zakat, sedekah, infaq, wakaf, tolong-menolong, dan sebagainya-, berikhtiar (berusaha) - dengan ilmu pengetahuan, teknologi, management dan lainlain-, berdo'a, dan bertaqarrub (mendekatkan diri) kepada Allah swt. Dengan kesadaran mengejawantahkan ini semua, maka keadilan sosial bagi seluruh rakyat Indonesia akan terwujud sesuai dengan cita-cita bersama.

Oleh karena itu, sila kelima ini - menurut Kyai Siddiq - menolak keras liberalisme dalam arti kebebasan bersaing secara bebas tanpa batas, baik di bidang politik, ekonomi, pendidikan, dan lain-lain.Sebab liberalisme demikian tidak dapat mengantarkan kepada keadilan sosial.Aturan main dalam perjuangan hidup bermasyarakat harus diatur sedemikian rupa, sehingga mendapatkan hasil yang seimbang dan merata bagi seluruh rakyat Indonesia.Yang lebih kuat harus diatur sehingga tidak menindas yang lebih lemah, dan yang lemah harus didorong dan dibantu untuk

18 “Lihat Achmad Siddiq, 'Norma-norma Pancasila Menurut Pandangan Islam', Makalah yang rencananya akan disampaikan dalam seminar di Aceh, karena sesuatu hal, sehingga tidak jadi dipresentasikan, terjadi pada tahun 1970-an," 11-12. 
mendapatkan sesuai dengan proporsinya. Ungkapan Kyai Siddiq tersebut relevan dengan konsep keadilan itu sendiri yang berarti "wadl'u syai' fi mahallihi (meletakkan sesuau sesuai dengan proporsinya)".

Memang menarik mengkaji sosok figur Kyai Siddiq ini, jika dilihat latar belakang pendidikannya yang dia tempuh hanya melalui pesantren, namun pemikiran-pemikirannya justru melampaui tradisi yang selama ini berjalan di pesantren pada umumnya. Hal demikian barangkali dikarenakan oleh situasi baik secara internal maupun eksternal dapat membentuk kepribadiannya. Kyai Siddiq memang lahir dan tumbuh di lingkungan keluarga yang sangat kondusif, baik tingkat pemahaman keagamaan maupun spiritualitasnya. Di samping itu, ditunjang juga oleh suasana pergulatan pemikiran dan pergaulannya dengan berbagai pihak, diikuti juga oleh tingkat kecerdasan, kharisma, dan kepiawaiannya sejak di usia muda. Oleh karena itu, tidak mengherankan jika Kyai Siddiq dianggap sebagai ulama yang melek tidak hanya soal-soal keagamaan namun juga menyangkut isu-isu kekinian, sehingga tidak sedikit yang menyebut Kyai Siddiq sebagai ulama intelektual modern NU. ${ }^{19}$ Kultur inilah yang dikembangkan oleh Kyai Siddiq dalam upaya mendobrak tatanan pesantren yang selama ini stagnan (cuek terhadap perubahan). Kemudian diikuti oleh generasi/santri NU berikutnya.Lebih-lebih ketika NU di bawah duet kepemimpinan Abdurrahman Wahid dan K.H. Achmad Siddiq. Keduanya dianggap dua sejoli yang dapat mengikuti geliat perubahan zaman, sehingga perubahan yang digagas oleh keduanya, saat ini memberikan implikasi yang sangat signifikan bagi generasi NU dan masyarakat Indonesia, khususnya pandangan-pandangannya menyangkut hubungan agama dengan kenegaraan, kebangsaan, dan Pancasila.

\section{Implikasi Pemikiran Kebangsaan K.H. Achmad Siddiq di Indonesia}

Sebagaimana di singgung pada pembahasan sebelumnya, bahwa Kyai Siddiq dimasukkan oleh Mujamil sebagai ulama NU yang memiliki tipologi pemikiran responsif terhadap berbagai persoalan kemummatan dan keagamaan. Oleh karena itu, setiap pemikiran, langkah dan gerakan yang dilakukan oleh Kyai Siddiq senantiasa membawa implikasi

${ }^{19}$ Syamsun Ni'am, The Wisdom of K.H. Achmad Siddiq: Membumikan Tasawuf, (Jakarta: Erlangga Press, 2009). 
yang tidak kecil.Lebih-lebih jika dikaitkan dengan perkembangan dan pertumbuhan pemikiran yang ada di Indonesia yang menyangkut ideologi bangsa.Dalam kaitan ini, Muhammad A.S. Hikam memberikan penegasan bahwa seorang cendekiawan sebagai salah satu elemen terpenting dalam civil society (masyarakat madani), secara historis memegang peran penting dalam proses pertumbuhan dan pemberdayaan (empowerment) dalam rangka menghadapi kekuatan negara. Di negara maju manapun, seorang cendekiawan dianggap sebagai pelopor bagi terwujudnya sebuah wilayah publik yang bebas (a free public sphere) yang akhirnya menjadi landasan bagi sebuah civil society yang mandiri. ${ }^{20}$ Dalam konteks ini, menelusuri implikasi pemikiran-pemikiran kebangsaan Kyai Siddiq - khususnya menyangkut hubungan Pancasila dan Islam - adalah menarik untuk disajikan.

Bila dirunut ke belakang, sebenarnya genealogi pemikiran kebangsaan Kyai Siddiq tidak dapat dilepaskan dari pemikiran para tokoh dan ulama pendahulunya. Dari aspek pemikiran keagamaan, pendidikan, hubungan agama dan Negara, konsep pembangunan kebangsaan (nation building), sosial politik, dan budaya, Kyai Siddiq berguru kepada ayahandanya, K.H. Muhammad Siddiq, pamannya, K.H. Mahfudz Siddiq, kemudian kepada K.H. A. Wahid Hasyim, Ir. Soekarno, Bung Hatta, dan Syahrir. ${ }^{21}$ Sedangkan pemikiran dan gerakan spiritualnya, Kyai Siddiq berguru kepada tokoh-tokoh ulama terhormat seperti Hadratus Syeikh Hasyim Asy'ari, K.H. Abdul Hamid Pasuruan, K.H. Abdul Halim Siddiq, K.H. Achmad Qusyairi, dan K.H. Hamim Djazuli (Gus Miek). ${ }^{22}$ Dengan demikian, Kyai Siddiq tidak hanya melek soal keagamaan semata, namun juga mengertisoal-soal politik, ekonomi, pendidikan, sosial-budaya, dan sebagainya. Inilah yang kemudian mengantarkan Kyai Siddiq sebagai ulama intektual organik, tidak hanya seorang ulama intelek yang mampu menggabungkan nilai-nilai dari tradisi lama yang dianggap baik untuk diselaraskan dengan nilai-nilai tradisi baru (modern) yang lebih baik, namun juga mampu meramu dan mendinamisasikan dengan perkembagan

${ }^{20}$ Muhammad A.S. Hikam, Demokrasi dan Civil Society (Jakarta: PT. Pustaka Lembaga Penelitian, Pendidikan, dan Penerangan Ekonomi-LP3ES Indonesia, 1996).

${ }^{21}$ Lihat Kacung Marijan, "Pesantren sampai Presiden," Jawa Pos, 24 Januari 1991; “In Memorium: K.H. Achmad Siddiq," Surya, 28 Januari 1991; Munawar Fuad Noeh dan Ma stuki HS, Menghidupkan Ruh Pemikiran K.H. Achmad Siddiq, 42.

${ }^{22}$ Abdul Halim Soebahar, "Arsitek Pemikiran Islam Indonesia (Catatan Biografi K.H. Achmad Siddiq)," in Penelitian, 2001, 21 dan 35; Syamsun Ni'am, The Wisdom of K.H. Achmad Siddiq: Membumikan Tasawuf, 2009, 36. 
zaman. Hal ini relevan dengan adagium yang selama ini dipegangi oleh kalangan Nahdliyyin (NU), yaitu menjaga dan melestarikan hal-hal lama yang dianggap baik dan mengambil hal-hal baru yang dianggap lebih baik dan bernilai maslahah (al-muhafadzatu 'ala al-qadim al-shalih wa al-akhdzu bi al-jadid al-ashlah).

Gagasan Kyai Siddiq yang memiliki pengaruh kuat bagi perkembangan bangsa Indonesia hingga sekarang adalah, gagasannya tentang penerimaan Pancasila sebagai ideologi atau dasar negara yang dianggapnya sudah final dalam kehidupan kenegaraan dan kemasyarakatan di Indonesia. Pancasila tidak perlu lagi dipertentangkan dengan Islam. ${ }^{23}$ Pernyataan tersebut walaupun dinyatakan Kyai Siddiqpada tahun 1983 ketika Munas (Musyawarah Nasional) alim ulama di Situbondo, namun implikasinya hingga kini masih sangat terasa ketika bangsa Indonesia dihadapkan pada adanya tuntutan dari sebagian kelompok masyarakat untuk mempersoalkan kembali Pancasila dan UUD 1945 sebagai ideologi bangsa, dan menginginkan kembali kepada Piagam Jakarta. Padahal keinginan untuk kembali kepada Piagam Jakarta (Jakarta Charter) merupakan ilusi dan tidak realistis dalam kehidupan kebangsaan di Indonesia. ${ }^{24}$

Penjabaran dari nilai-nilai yang terkandung dalam Pancasila tersebut, diejawantahkan oleh Kyai Siddiq ke dalam ukhuwwah. Menurut Kyai Siddiq, ukhuwwah Islamiyyah tidak hanya terbatas pada umat Muslim saja, tapi mencakup ukhuwwah wathaniyyah dan ukhuwwah basyariyyah, karena sejak semula kedua ukhuwwah yang disebut terakhir itu telah tercakup dalam ukhuwwah Islamiyyah itu sendiri. Kyai Siddiq mengelaborasi lebih lanjut, bahwa term persaudaraan Islam (ukhuwwah Islamiyyah) bukanlah persaudaraan yang bersifat eksklusif, persaudaraan yang terbatas pada umat Islam saja, namun juga persaudaraan yang luas, persaudaraan yang meliputi orang ateis sekali pun selama mereka tidak berniat memusuhi umat Islam. Ukhuwwah Islamiyyahbagi Kyai Siddiqmerupakanukhuwwah 'ind al-Islam (persaudaraan menurut versi

${ }^{23}$ Anwar Hudijono, "'K.H. Achmad Siddiq; Akar Menghujam-Batang Menjulang,'” n.d.; Einar M. Sitompul, Nahdlatul Ulama dan Pancasila (Jakarta: Pustaka Sinar Harapan, 1989), 177.

${ }^{24}$ Syamsun Ni'am, The Wisdom of K.H. Achmad Siddiq: Membumikan Tasawuf, 2009, $172-73$. 
Islam). ${ }^{25}$ Dengan demikian, ukhuwwah Islamiyyahsebenarnya cakupannya luas sekali dan inklusif, lintas agama, negara, ras, dan sebagainya. ${ }^{26}$ Konsep ukhuwwah yang dikembangkan Kyai Siddiq ini memiliki implikasi pada suatu pandangan tentang pentingnya nilai-nilai kesamaan derajad di antara manusia (egalitarianisme dan kosmopolitanisme).Pandangan seperti ini sebenarnya dapat dijumpai dari banyak literatur klasik, khsusunya dalam perbendaharaan sufi-sufi masa lampau. Sebab dalam perspektif sufi, semua umat manusia mempunyai kedudukan yang sama di hadapan Allah swt., yang membedakannya adalah tingkat ketaqwaannya.

Implikasi jauh dari pernyataan di atas, umat Islam mestinya bisa melepaskan anggapan bahwa hidup itu harus secara berkelompok dalam wadah oraganisasi Islam, juga menghilangkan anggapan bahwa orang Islam adalah orang-orang yang mempunyai cita-cita ideologi Islam. Dengan demikian, cita-cita Islam adalah berwawasan nasional, tidak lagi berwawasan golongan, bahkan harus berwawasan internasional. Menurut Kyai Siddiq, "umat Islam adalah mereka yang bersahabat, percaya dan menyaksikan bahwa tidak ada Tuhan yang disembah kecuali Tuhan Yang Maha $E s a^{\prime \prime}{ }^{27}$ Kyai Siddiq telah mengkontekstualisasikan nilai-nilai teologis dan persahabatan itu ke dalam tataran praktis.Barangkali hanya Kyai Siddiq selama memimpin organisasi massaNU, yang bisamempertemukan dan menggandengkan dua tangan dalam jalinan erat (ukhuwwah) - yang pada waktu itu hubungan kedua organisasi Islam (NU dan Muhammadiyah) itu terlihat agak jauh. Bey Arifin pun menilai langkah Kyai Siddiq ini dengan memberikan apresiasi: "Beliau adalah ulama` besar, 'alim, dan sulit dicari penggantinya. Kita semua tahu, sejak zaman Belanda, NU dan Muhammadiyah agak jauh.Tapi dengan kepemimpinan beliau, sekarang dua organisasi itu menjadi rapat dan baik". ${ }^{28}$ Jalinan $u k h u w w a h$ yang dilakukan Kyai Siddiq telah berhasil gemilang dan implikasi yang

${ }^{25}$ Mujamil Qomar, NU "Liberal" dari Tradisionalisme Ahlussunnah ke Universalisme (Bandung: Mizan, 2002), 163.

${ }_{26}$ Andi Bahruddin Malik, “K.H. Achmad Siddiq (1926-1991): Sosok Ulama NU Liberal, Menjernihkan hubungan Pancasila dan Islam Rosehan Anwar dan Andi Bahruddin Malik, Ulama dalam Penyebaran Pendidikan dan Khazanah Keagamaan (Jakarta: Proyek Pengkajian dan Pengembangan Lektur Pendidikan Agama Balitbang Agama dan Diklat Keagamaan Depag RI, 2003).

${ }^{27}$ Munawar Fuad Noeh dan Mastuki HS. (Ed.), Menghidupkan Ruh Pemikiran K.H. Achmad Siddiq, Cet. I (Jakarta: Logos, 1999), 99-101.

${ }^{28}$ Bey Arifin, “Kesan-kesan Tokoh,” dalam Jawa Pos, 24 Januari 1991. 
ditinggalkannya sangat terasa hingga kini, sehingga hambatan-hambatan baik psikologis maupun teologis bisa dianulir dengan baik, dan tidak ada lagi yang perlu dipertentangkan antar umat Islam.Kalaupun masih ada, gaungnya tidak seheboh pada saat sebelum Kyai Siddiq memimpin NU.

Selain itu, implikasi yang muncul dari pandangan Kyai Siddiq tentang hubungan Pancasila dan Islam - yang masih tetap dirasakan hingga saat ini- adalah adanyapemahaman dari para pemimpin NU dan warganya yang masih konsisten untuk melanjutkan butir-butir kesepakatan para ulama NU yang dikomandoi oleh Kyai Siddiq, sehingga dapat dipahami bahwa hingga kapanpun dan siapapun yang melanjutkan kepemimpinan NU ke depan, akan selalu menjaga, melestarikan, dan mengembangkan konsepsi hubungan Pancasila dan Islam ini di bumi Indonesia. Sebagai bukti kekonsistenan NU dan warganya dalam mempertahankan Pancasila, adalah misalnya ketika muncul upaya untuk merongrong Pancasila dari sebagian kelompok di Indonesia - melalui propaganda dengan memanfaatkan berbagai medsos (media sosial) yang ada dan lainnya-, NU dalam setiap kesempatan seakan telah menjadi garda terdepan dalam membela dan mempertahankan dengan berbagai strategi dakwah kultural dan politiknya, di saat hampir sebagian besar kelompok baik oragnisasi massa maupun organisasi politik di negeri ini, telah ragu-ragu -jika mungkin terlalu hati-hati-, bahkan tidak berani secara tegas dan nyata dalam mendukung Pancasila. Konsekuensinya adalah munculnya keberanian dari warga NU untuk mengatakan bahwa Pancasila, Bhinneka Tunggal Ika, Negara Kesatuan Republik Indonesia (NKRI), dan UUD '45 adalah sesuatu yang tidak bisa ditawar-tawar lagi - bahkan wajib 'ain bagi setiap warganya-dalam kehidupan berbangsa dan bernegara di Indonesia. Oleh karena itu, empat pilar tersebut saat ini sangat populer dengan nama PBNU (Pancasila, Bhinneka Tunggal Ika, NKRI, dan UUD '45). Lebih-lebih yang mempopulerkan singkatan ini adalah ulama yang sangat berpengaruh di NU, yaitu K.H. Maimoen Zubair (Mbah Moen), pengasuhPondok Pesantren al-Anwar Desa Karangmangu, Sarang, Rembang, Jawa Tengah, dan juga Mustasyar PBNU (Pengurus Besar Nahdlatul Ulama).

Urgensitas Pancasila dalam kehidupan berbangsa dan bernegara oleh Kyai Siddiq ditegaskan kembali oleh Mbah Moen dengan mengatakan: “Empat pilar itulah (Pancasila, Bhinneka Tunggal Ika, NKRI, dan UUD '45) 
yang harus dijalankan oleh warga Nahdliyyin, ini yang harus diketahui, kalau orang NU nggak mau Pancasila, yo ora patek NU (ya nggak begitu NU)". Mbah Moen melanjutkan, bahwa Islam merupakan agama yang melarang ashabiyah atau fanatisme kelompok.Ia mengajak ummat Islam untuk tetap menjunjung tinggi ukhuwwah Islamiyah atau persaudaraan sesama ummat Islam". ${ }^{29}$ Pandangan Mbah Moen sinergis dengan pandangan Kyai Siddiq dalam mengartikulasikan hubungan Pancasila dan Islam.Ini sekaligus menjadi bukti bahwa di kalangan NU, antara Pancasila dan Islam adalah sudah final, dan selalu bisa bersinergi dan tidak perlu dipertentangkan.

\section{E. Simpulan}

Kyai Siddiq adalah seorang ulama intelektual yang telah berhasil meletakkan dasar-dasar ideologis Pancasila dalam kehidupan bermasyarakat, berbangsa dan bernegara. Implikasi dari gagasan-gagasan pemikiran yang ditanam olehnya sangat terasakan hingga hari ini -jika dihitung sejak keputusan Munas (Musyawarah Nasional) alim ulama di Situbondo tahun 1983 tentang penerimaan Pancasila sebagai azas NU hingga sekarang, berarti sudah berusia 34 tahun - di saat bangsa Indonesia dihadapkan pada disintegrasi pemahaman dalam praktek keberagaman dan keberagamaan. Oleh karena itu, butir-butir pemikiran Kyai Siddiq dirasa sangat penting untuk selalu dikaji, dipelajari, diajarkan, dikembangkan dalam setiap aspek kehidupan masyarakat Indonesia baik melalui pendikan formal, informal maupun non-formal. Pemikiran kebangsaan Kyai Siddiq, khususnya menyangkut hubungan Pancasila dan Islam sengaja dihadirkan adalah untuk mereview kembali pandangan seorang ulama yang memiliki pemahaman komprehensif dan universal. Selain itu, review pemikiran Kyai Siddiq ini menjadi sangat urgen di saat para generasi penerus bangsa yang tidak banyak yang mengetahui dan mengerti tentang Pancasila sengaja dipilih oleh founding fathers (para pendiri bangsa) sebagai ideologi dan common platform bangsa Indonesia, baik dilihat dari aspek sejarah politik Indonesia maupun substansi prinsip-prinsip yang terkandung di dalamnya dan hubungannya dengan ajaran Islam untuk diimplementasikan dalam kehidupan bermasyarakat,

29 "Mbah Moen: Kalau NU Tidak Pancasila, Ya Bukan NU," Liputan6.com, 26 Mei 2017. 
berbangsa dan bernegara, di mana mayoritas pemeluk agama di Indonesia adalah Muslim.

Dengan melihat dan mereview kembali pandangan-pandangan para tokoh Islam Nusantara - termasuk Kyai Siddiq- misalnya menyangkut hubugan agama-negara, Pancasila-Islam, Demokrasi-Islam, dan lain-lain, maka akan diketahui secara komprehensip bagaimana cara/metode dan strategi para tokohnya dalam mengkontekstualisasikan pemahaman keberagamaannya di tengah masyarakat yang beragam (bhinneka) seperti di Indonesia, sehingga kompleksitas pemikirannya dapat menginspirasi bahkan menjadi sanad (transmitter) otentik dan dapat dipertanggungjawabkan sampai kapanpun. Di samping itu, para pendiri bangsa tersebut dapat menunjukkan cara atau strateginya dalamberjihad, berijtihad, dan menyelesaikan problem-problem keummatan dan kebangsaan yang sewaktu-waktu bisa saja berpotensi kepada konflik(perpecahan); untuk selanjutnya dapat dibaca dan dijadikan uswah (teladan), sehingga dalam menatap masa depan Indonesia yang lebih cerah dan sejahtera dapat diwujudkan secara baik[.]

\section{REFERENSI}

Abdul Halim Soebahar. "Arsitek Pemikiran Islam Indonesia (Catatan Biografi K.H. Achmad Siddiq).” In Penelitian. Jember, 2001.

Afton Ilman Huda. Biografi Mbah Siddiq. Jember: Pon. Pes. Al-Fattah, n.d.

Anwar Hudijono. "'K.H. Achmad Siddiq; Akar Menghujam-Batang Menjulang.'” n.d.

Baca Soekarno. Lahirnya Pancasila, dalam Tujuh Bahan Indoktrinasi. Jakarta: DPA, 1961.

"Berdasarkan kajian mutakhir, bahwa Indonesia adalah Negara yang sangat plural, yang terdiri dari 17 ribu pulau lebih, 34 propinsi dan 516 kabupaten/kota, 714 suku, dan 1.211 bahasa daerah." Jawa Pos, 18 Agustus 2017.

Bey Arifin. "Kesan-kesan Tokoh." dalam Jawa Pos, 24 Januari 1991.

Deliar Noer. Gerakan Modern Islam di Indonesia 1900-1942. Jakarta: LP3ES, 1996. 
Einar M. Sitompul. Nahdlatul Ulama dan Pancasila. Jakarta: Pustaka Sinar Harapan, 1989.

“In Memorium: K.H. Achmad Siddiq.” Surya, 28 Januari 1991.

Kacung Marijan. "Pesantren sampai Presiden." Jawa Pos, 24 Januari 1991.

K.H. Achmad SIddiq. "Hubungan Agama dan Pancasila." In Pertemuan Ilmiah, 14. Jakarta: Balitbang Agama Departemen Agama RI, 1985.

“Kyai Achmad." In AULA: Risalah NU, Vol. 8. 2. Surabaya: PWNU Jawa Timur, 1991.

"Lihat Achmad Siddiq, 'Norma-norma Pancasila Menurut Pandangan Islam', Makalah yang rencananya akan disampaikan dalam seminar di Aceh, karena sesuatu hal, sehingga tidak jadi dipresentasikan, terjadi pada tahun 1970-an," n.d.

“Mbah Moen: Kalau NU Tidak Pancasila, Ya Bukan NU." Liputan6.com, 26 Mei 2017.

Muhammad A.S. Hikam. Demokrasi dan Civil Society. Jakarta: PT. Pustaka Lembaga Penelitian, Pendidikan, dan Penerangan Ekonomi-LP3ES Indonesia, 1996.

Mujamil Qomar. Fajar Baru Islam Indonesia?Kajian Komprehensif atas Arah Sejarah dan Dinamika Intelektual Islam Nusantara. Bandung: Mizan, 2012.

- - - NU "Liberal" dari Tradisionalisme Ahlussunnah ke Universalisme. Bandung: Mizan, 2002.

- - - . NU "Liberal" dari Tradisionalisme Ahlussunnah ke Universalisme Islam. Bandung: Mizan, 2002.

Munawar Fuad Noeh, dan Mastuki HS, ed. Menghidupkan Ruh Pemikiran K.H. Achmad Siddiq. 1 ed. Jakarta: Logos, 1999.

Munawar Fuad Noeh, dan Mastuki HS. (Ed.). Menghidupkan Ruh Pemikiran K.H. Achmad Siddiq. Cet. I. Jakarta: Logos, 1999.

Munawir Aziz, Akhmad Sahal. Baca Abdul Moqsith Ghazali, "Metodologi Islam Nusantara", dalam Islam Nusantara: Dari Ushul Figh hingga Paham Kebangsaan. Cet. II. Bandung: Mizan, 2015.

Nubowo, Andar. "Islam dan Pancasila di Era Reformasi: Sebuah Reorientasi Aksi," n.d., 18. 
Nurcholish Madjid. Islam Indonesia Menatap Masa Depan: Aktualisasi Ajaran Ahlussunnah Waljama'ah", dalam Akhmad Sahal dan Munawir Aziz (ed.), Islam Nusantara: Dari Ushul Figh hingga Paham Kebangsaan. Cet. II. Bandung: Mizan, 2015.

Prawoto Mangkusasmito. Pertumbuhan Historis Rumus Dasar Negara dan Sebuah Proyeksi. Jakarta: Hudaya, 1970.

Ridwan Fakla AS.(Ed.), Humaidy Abdussami. Biografi 5 Rais 'Am Nahdlatul Ulama. Yogyakarta: LTn-NU dan Pustaka Pelajar, 1995.

Rosehan Anwar, dan Andi Bahruddin Malik. Ulama dalam Penyebaran Pendidikan dan Khazanah Keagamaan. Jakarta: Proyek Pengkajian dan Pengembangan Lektur Pendidikan Agama Balitbang Agama dan Diklat Keagamaan Depag RI, 2003.

Said Aqil Siroj. Islam Sumber Inspirasi Budaya Nusantara Menuju Masyarakat Mutamaddin. Jakarta: LTN NU, 2014.

Syamsun Ni'am. The Wisdom of K.H. Achmad Siddiq: Membumikan Tasawuf,. Jakarta: Erlangga Press, 2009.

- - - . The Wisdom of K.H. Achmad Siddiq: Membumikan Tasawuf,. Jakarta: Erlangga Press, 2009. 